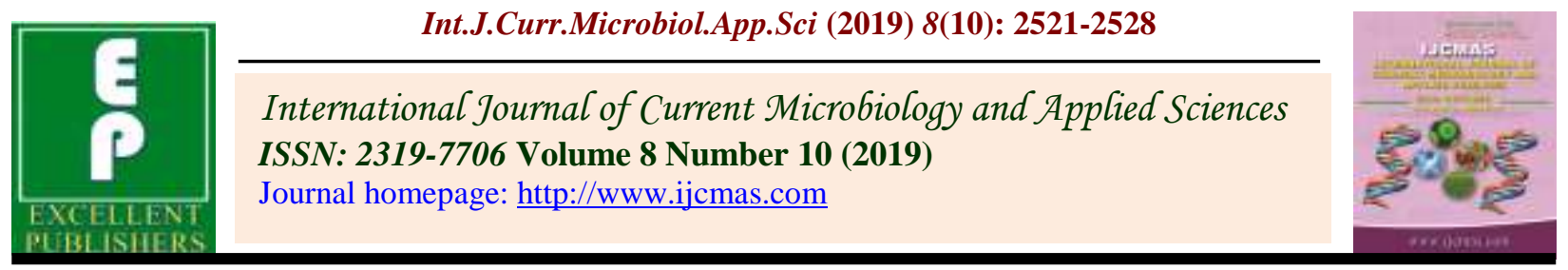

Original Research Article

https://doi.org/10.20546/ijcmas.2019.810.292

\title{
New Record of Trichogaster lalius (Hamilton, 1822) from Thippagondanahalli Reservoir (Cauvery River Basin)
}

\author{
V. L. Ramya*, S. Sibina Mol, D. S. Krishna Rao, Preetha Panikkar, M. Karthikeyan, \\ P. K. Jesna, M. E. Vijaykumar and U. K. Sarkar
}

ICAR-Central Inland Fisheries Research Institute, Heasarghatta, Bangalore-560089, India

*Corresponding author

\begin{tabular}{|l|}
\hline Ke y w o r d s \\
$\begin{array}{l}\text { Trichogaster lalius, } \\
\text { Thippagondanahalli, } \\
\text { Cauvery, Gourami, } \\
\text { Reservoir }\end{array}$ \\
\hline Article Info \\
\hline $\begin{array}{l}\text { Accepted: } \\
18 \text { September } 2019 \\
\text { Available Online: } \\
10 \text { October } 2019\end{array}$ \\
\hline
\end{tabular}

Keywords

Trichogaster lalius, Thippagondanahalli, Cauvery, Gourami, Reservoir

Article Info

18 September 2019

10 October 2019

\section{A B S T R A C T}

Cauvery river system is one of the major freshwater aquatic systems in Peninsular India with a number of tributaries and reservoirs on it. The system inhabits a variety of endemic fish species. Thippagondanahalli Reservoir (TR) is a medium reservoir on Arkavathy River, a tributary of River Cauvery. This report is on the first record of dwarf gourami, Trichogaster lalius belonging to the family, Osphronemidae, from the TR. The reservoir is located in Bengaluru South Taluk, Karnataka $\left[13^{\circ} 02^{\prime} 41^{\prime \prime} \mathrm{N} 77^{\circ} 36^{\prime} 24^{\prime \prime} \mathrm{E}\right.$; Area at FRL (Full Reservoir level): 1162.0 ha]. A total of nine specimens of the species were collected from the reservoir during various seasons (pre-monsoon, monsoon, post-monsoon) in 2015-16. It is a species having high value in the ornamental fish industry and a great demand in international market. Population study and proper management practices will help to improve the population of the species; will add on fisherman income and improve their livelihood. Further studies are required to find the parent population of $T$. lalius. The introduction of $T$. lalius in TR may be accidental and the macrophytes in the reservoir being suitable for the inhabitation of the species would have supported in establishing the population.

\section{Introduction}

Thippagondanahalli Reservoir, also known as Chamarajasagar, is built at the confluence of the Arkavathy and Kumudavathi rivers, the tributaries of R. Cauvery, $35 \mathrm{~km}$ west of Bangalore, India (Figure 1). It is a source of drinking water for western Bangalore and is under the control of Bangalore Water Supply and Sewerage Board (BWSSB). The total catchment area of TR is $1453 \mathrm{~km}^{2}$. The reservoir has an area of 1162.0 ha at FRL. River Cauvery is one of the most remarkable rivers of peninsular India originating in the Brahmagiri range of the Western Ghats in Kodagu district, Karnataka at an elevation of $4340 \mathrm{~m}^{1}$. This Cauvery system harbours a good number of endemic and indigenous fishes. Among them, Labeo calbasu, Tor khudree, Osteochelius thomassi, Schismatorhyncus nukta and Systomus sarana are native to the river. Garra mullya, 
Hypselobarbus micropogon, Longischistura bhimachari, Mesonoemacheilus pulchellus, Puntius parrah, Salmostoma belachi Gonoproktopterus dubiu and Labeo kontius are few endemic species recorded from the river. This river system also harbours exotic fishes such as Cyprinus carpio, Oreochromis mossambicus, O. niloticus, Clarius garipienus, Ctenopharyngodon idella, Hypophthalmichthys molitrix, Pterygoplichthys disjunctivus was recorded from the river ${ }^{2}$.

The species Trichogaster lalius, popularly known as "dwarf gourami" belonging to the family, Osphronemidae is native to south Asia. This species is distributed in the states of Arunachal Pradesh, Assam, Bihar, Manipur, Uttaranchal, Uttar Pradesh and West Bengal $^{3}$. The occurrence of this species has been reported in the lowland Ganges and Brahmaputra basins. Feral populations have been reported from Singapore, the USA and Colombia. The distribution records are shown in Table 1.

Trichogaster lalius is a freshwater ornamental fish species with oblique bands of orange colour from back to the abdomen in males and the females are silver colored. Trichogaster spp. shows finnage dimorphism. The male's dorsal fin is longer than the female's and reaches back to the caudal peduncle. It attains a maximum length of 8.8 $\mathrm{cm}$ length ${ }^{4}$. It is a hardy species and can breathe air from the surface with the aid of an accessory respiratory organ, the labyrinth ${ }^{5,6,7}$. The mature male is brightly coloured with red and blue bands. The mature female is less colorful but has an attractive silver body. Its bright color and ease-adaptive to captive nature makes it popular for aquarium fish. Colour is considered to be one of the major factors which determine the cost of aquarium fish in the world market. Different varieties in the dwarf fish such as red, neon blue, neo, golden and regular are available in international market. Hence this fish has high economic value in markets and fetches high price in the average of $\$ 32$ for each ${ }^{8}$.

The habitats of this fish are slow moving streams, rivulets and lakes with plenty of vegetation. It requires high protein feed for their growth and coloration. The dwarf gourami takes 8 to 12 months to mature in temperate areas like northern India ${ }^{8}$.

There are no records on the occurrence of $T$. lalius in the Cauvery river system as well as from other peninsular river basins. The present record may be considered as the first record of T. lalius in Cauvery river basin.

\section{Materials and Methods}

Seasonal samples for habitat characteristics and fish assemblages were collected by operating multi-meshed experimental gillnet in Thippagondanahalli reservoir during premonsoon, monsoon and post-monsoon seasons of 2016-17. T. lalius was recorded in littoral and limnetic sites of lentic and intermediate zones during all the three seasons.

A total of nine specimens were collected. Two specimens were taken in live condition to the laboratory and observed in aquarium for their behavior. The rest were fixed in $10 \%$ formalin for further studies. The meristic characters were noted and the morphometric measurements were taken using a Vernier caliper to the nearest $0.1 \mathrm{~mm}$ following the method ${ }^{9}$.

The physico-chemical parameters of water viz. temperature, $\mathrm{pH}$, transparency and specific conductivity were recorded by using Standard digital field kit (HQ40d, 582580) and dissolved oxygen and alkalinity were analysed following standard methods ${ }^{10}$. 


\section{Results and Discussion}

The unplanned development in catchment area and increasing urbanization has led to alterations in the drainage pattern and hence reducing inflow in to the TR. The mean depth of this reservoir is approximately $10 \mathrm{~m}$. The water temperature was $28^{\circ} \mathrm{C}$, Secchi disc transparency, being low due to organic turbidity, was up to $60 \mathrm{~cm}$ and $\mathrm{pH}$ was highly alkaline (8.5). The dissolved oxygen was in satisfactory concentration $(7.6 \mathrm{mg} / \mathrm{l})$ in surface layers but was almost zero below $5 \mathrm{~m}$ depth. The water was soft with total alkalinity of $230 \mathrm{mg} / \mathrm{l}$ and moderate ionic concentration (specific conductivity of $2.82 \mathrm{mS} / \mathrm{cm}$ ). The reservoir can be classified as eutrophic based on water quality parameter and the occurrence of algal bloom during study period.

The reservoir is organically polluted and the habitat has high algal density abundance of macrophytes such as Echhornia, indicate the heavy organic pollution.

T. lalius is unresponsive in gill modification during acidic condition because of the high protein expression and enzyme activity of vacuolar-type $\mathrm{H}+$-ATPase (Huang $\mathrm{C}$. Y and Lin, H. C. 2011). According to the present study, highly alkaline water of TR may support the growth of $T$. lalius.

During the sampling, we have recorded the specimens belonging to the genus Trichogaster in the size range of 4.2 to $4.9 \mathrm{~cm}$ in total length and 1.5 to $3.7 \mathrm{~g}$ in weight. Maximum size reported is $8.8 \mathrm{~cm}$ length ${ }^{4}$. The fishes were identified as Trichogaster based on the characters such as egg shaped and strongly compressed body, small mouth strongly protrusible, lips normal, pre-orbital denticulate, soft dorsal and anal rounded; caudal fin rounded to truncate, scales large: 27 or 28 in longitudinal series; anal fin densely scaled, scales covering fin to tips of the posterior spine meristic characters of fin such that D XV-XVII/7-10, A XVIII/13-17, P 10. Coloration of the body mainly scarlet, crossed by oblique bands of pale blue, fins with scarlet spots or bars; anal fin with red mark $^{11}$.

The meristic and morphometric characters of the collected specimens, described in the Table 2 and 3, were compared ${ }^{9}$ and concluded that the specimens are T. lalius Figure 2.

Five farms raise dwarf gouramis commercially in Singapore. Four different varieties of dwarf gouramis are raised on these farms- red neon dwarf, neon dwarf, golden dwarf and regular dwarf gouramis ${ }^{8}$. In international market gourami fetches high prizes because of its colour and behaviour. Colour is considered to be one of the major factors which determine the cost of aquarium fish in the world market and hence gouramies have a high economic value ${ }^{12}$.

Spawning behavior of this fish needs lot of vegetation. Male guards the floating bubblenest where the eggs are laid, about 600 in number. Hatching takes place in 12 to 24 hours while the male parent continues to protect the nest.

In about three days, the developing larvae become free-swimming and leave the nest ${ }^{13}$. Male guards the floating bubble-nest where the eggs are laid, about 600 in number. Hatching takes place in 12 to 24 hours while the male parent continues to protect the nest. In about three days, the developing larvae become free-swimming and leave the nest (Riehl and Baensch, 1991).

The habitat of this fish is mainly slow moving streams, and lakes, it needs lot of vegetation for their population establishment and hiding nature. 
Table.1 Distribution of T. lalius

\begin{tabular}{|c|c|c|c|}
\hline S. No & Species & Distribution & Authors \\
\hline 1 & T. lalius & Beki River, Barpeta, Assam & $\begin{array}{l}\text { Kalita and Sarma, } \\
2015\end{array}$ \\
\hline 2 & T. lalius & $\begin{array}{l}\text { Belda, Paschim Medinipur, West } \\
\text { Bengal }\end{array}$ & $\begin{array}{l}\text { Paul and Chanda, } \\
2015\end{array}$ \\
\hline 3 & T. lalius & River Island Majuli, India & $\begin{array}{lr}\text { Hazarika } & \text { and } \\
\text { Bordoloi, } 2015\end{array}$ \\
\hline 4 & T. lalius & Central and Eastern Regions of India & Awasthi et al., 2015 \\
\hline 5 & T. lalius & $\begin{array}{l}\text { Subansiri river drainage, Northeast } \\
\text { India }\end{array}$ & Bakalial et al., 2014 \\
\hline 6 & T. lalius & South Tripura & $\begin{array}{l}\text { Mandal and Barman, } \\
2014\end{array}$ \\
\hline 7 & T. lalius & Bangladesh; India, Nepal; Pakistan & Vishwanath, 2010 \\
\hline 8 & T. lalius & Bangladesh & Islam et al., 2015 \\
\hline 9 & T. lalius & Brahmaputra River, Bangladesh & Galib, 2015 \\
\hline 10 & T. lalius & Padma River, Bangladesh & Joadder et al., 2015 \\
\hline 11 & T. lalius & Tamilnadu & $\begin{array}{l}\text { Raghunathan et al., } \\
\text { 2005; Knight, 2010; } \\
\text { Daniels } \\
\text { Rajagopal, } 2004\end{array}$ \\
\hline
\end{tabular}

Table.2 Meristic characteristic of $T$. lalius

\begin{tabular}{|l|l|}
\hline Meristic Data & Numbers \\
\hline Dorsal fin Spines + Branched rays & XVI-XVII 7-8 \\
\hline Anal fin Spines + Branched rays & XVI-XIX 13-14 \\
\hline Pectoral fin rays & $8-9$ \\
\hline Caudal fin rays & $16-18$ \\
\hline Lateral line scales & $29-32$ \\
\hline
\end{tabular}


Table.3 Morphometric measurements of T. lalius

\begin{tabular}{|l|l|l|}
\hline Measurements & Mean (g/mm) & Range (g/mm) \\
\hline Weight of fish(g) & $2.43 \pm 0.21$ & $1.50-3.70$ \\
\hline Total length & $46.27 \pm 0.97$ & $42.44-49.70$ \\
\hline Standard length & $37.29 \pm 0.78$ & $34.03-40.65$ \\
\hline Head length & $11.13 \pm 0.40$ & $9.77-13.48$ \\
\hline Head depth & $14.51 \pm 0.39$ & $12.46-15.81$ \\
\hline Inter orbital width & $5.30 \pm 0.23$ & $4.30-6.42$ \\
\hline Snout length & $2.66 \pm 0.06$ & $2.43-2.95$ \\
\hline Eye diameter & $3.49 \pm 0.10$ & $3.02-3.89$ \\
\hline Body Depth & $19.10 \pm 0.73$ & $17.46-19.90$ \\
\hline Body width & $5.98 \pm 0.33$ & $4.72-7.78$ \\
\hline Dorsal fin base length & $20.71 \pm 0.47$ & $18.28-22.71$ \\
\hline Pectoral fin base length & $2.01 \pm 0.19$ & $1.43-2.96$ \\
\hline Anal fin base length & $21.13 \pm 0.62$ & $19.16-25.03$ \\
\hline Caudal peduncle depth & $6.47 \pm 0.30$ & $5.25-8.05$ \\
\hline Pelvic fin extension & $31.81 \pm 0.58$ & $29.40-34.53$ \\
\hline Distance between snout and dorsal & $15.07 \pm 0.39$ & $13.83-17.41$ \\
\hline Distance between dorsal and caudal & $4.13 \pm 0.20$ & $3.34-5.06$ \\
\hline Dorsal-pectoral distance & $12.24 \pm 0.24$ & $11.28-13.23$ \\
\hline Dorsal-pelvic distance & $17.53 \pm 0.34$ & $16.21-19.21$ \\
\hline Dorsal-anal distance & $18.06 \pm 0.97$ & $16.09-19.45$ \\
\hline Inter-nares width & $3.14 \pm 0.18$ & $2.45-3.97$ \\
\hline Pre-anal distance & $17.69 \pm 0.40$ & $16.47-19.89$ \\
\hline & & \\
\hline
\end{tabular}


Fig.1 Thippagondanahalli Reservoir, Arkavathy river basin (Star indicate the locality of T. lalius)

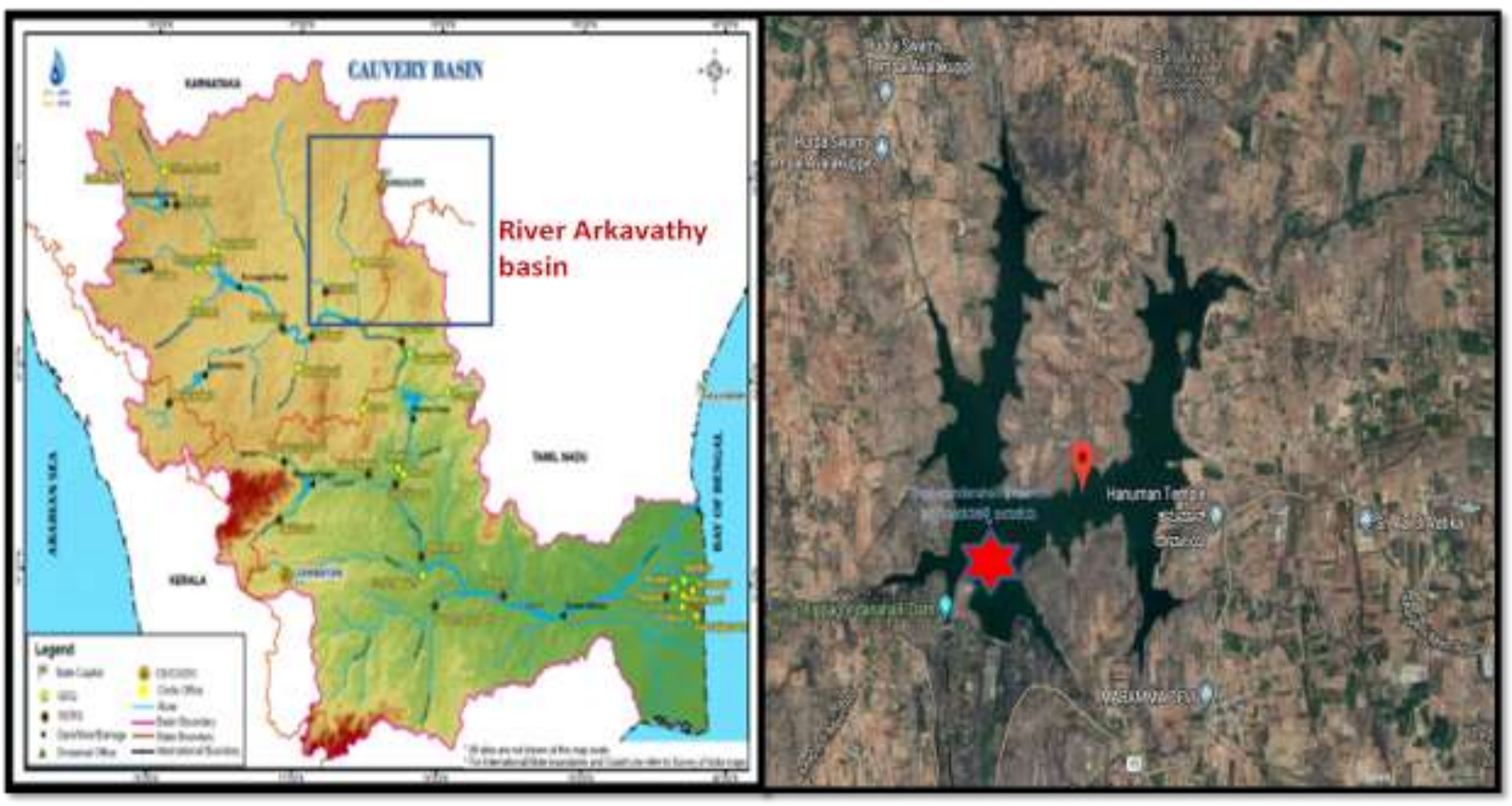

Fig.2 Male and Female specimens of Trichogaster lalius

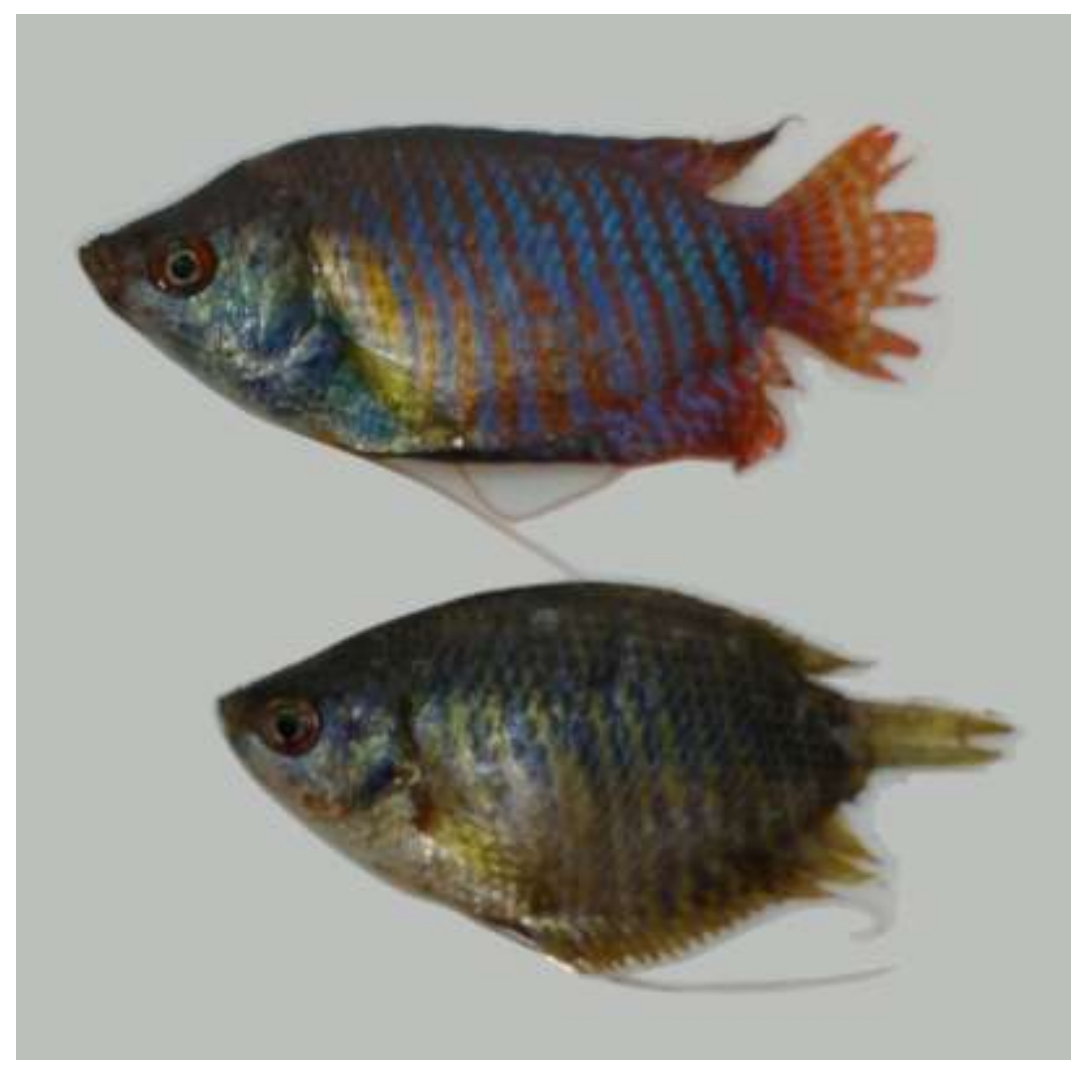


It used to make bubble nest under macrophytes. T. lalius is an exotic to Cauvery river system but it is our native fish to north east region of India. Invasive species are considered as one of the major causes of devastation of native fish biodiversity in freshwater ecosystem. Invasive species program from US forest service formed few criteria for invasive species (USDA, 2016). $T$. lalius may not be an invasive species, because of its small size, calm nature and wide range of feeding habits. This species is not harming environment or other native fishes ${ }^{4}$. Further studies are required to understand the habitat and behavior of this fish.

T. lalius has a good ornamental value and Thippagondanahalli reservoir is a habitat suitable for this fish species. Awareness on collection and marketing of this fish can improve the livelihood of fishermen. At the same time good management practices and population study of $T$. lalius is also important to identify the parent population and for their conservation.

\section{References}

AbuBakar, S., 1972. Preliminary study on the breeding habits, embryology and early development of the dwarf gourami, Colisu luliu (Hamilton-Buchanan), In Master's thesis. University of Singapore, Fisheries Biology Unit, Singapore.

APHA, 1988. Standard methods for the examination of water and waste water (Ed. Washington D. C), American Public Health Association.

Awasthi, M., Kashyap, A. and Serajuddin, M., 2015. Length_Weight Relationship and Condition Factor of Five Sub_Populations of Trichogaster lalius (Osphronemidae) of Central and Eastern Regions of India. J. Ichthyol. $55,849-853$
Bakalial, B., Biswas, S. P., Borah, S. and Baruah, D., 2014. Checklist of fishes of Lower Subansiri river drainage, Northeast India. Ann. Biol. Research, 5, 55-67

Daniels, R. J. R. and Rajagopal, B., 2004. Fishes of Chembarampakkam Lake A wetland in the outskirts of Chennai. Zoos' Print J. 19, 1481-1483.

Froese, R. and D. Pauly. FishBase. Trichogaster lalius (Hamilton, 1822). India Biodiversity Portal, 2013 , Available at: http://indiabiodiversity. org/biodiv/species/show/233749

[Accessed date Oct 28, 2016].

Galib, S. M., 2015. Fish fauna of the Brahmaputra River, Bangladesh: richness, threats and conservation needs. J. Fish., 3, 285-292.

Hazarika, A. K. and Bordoloi, R., 2015. Biodiversity and conservation status of Ichthyofauna of the river Island Majuli, India. Sch. Acad. J. Biosci. 3, 878-885

Islam, A., Hossain, M. M., Ahsan, M. E. and Nahar, A., 2015. Status and current worries of fish diversity in the Payra river, Patuakhali, Bangladesh Md. Int. J. Fish. Aquat. Stud., 2, 160-165

Jayaram, K. C., 2002. In Fundementals of fish taxonomy. Narendra publishing House, Delhi. pp. 1-172.

Joadder, A. R., Galib, S. M., Haque, M. and Chaki, N., 2015. Fishes of the river Padma, Bangladesh: Current trend and conservation status. J. Fish. 3, 259266.

Kalita G. J. and Sarma P. K., 2015. Ichthyofaunal diversity, status and Anthropogenic stress of Beki River, Barpeta, Assam. Int. J. Fish. Aquat. Stud. 2, 241-248.

Knight, M. J. D. 2010. Addressing the wallacean shortfall: an updated Checklist of icthyofauna of 
Chembarampakkam tank, Taprobanica, 2, 25-29.

Mandal, S. C. and Barman, D., 2014. Identification of the Most Potential Indigenous Ornamental Fishes of South Tripura District in India for Commercial Production, Int. J. Aquacult., 2014, 4, 43-47

Menon, A.G.K., 1999. Check list - fresh water fishes of India. Rec. Zool. Surv., India, Misc. Publ., Occas. Pap., 175, 366.

Munshi, J. S. D. 1976. Gross and fine structure of the respiratory organs of air-breathing fish. In Respiration of Amphibious Vertebrates (ed. G. M. Hughes), London Academic Press, pp. 73-104.

Munshi, J. S. D., 1968. The accessory respiratory organs of Anabas testudineus (Bloch) (Anabantidae, Piesces). Linn. Sic. Pro. 179, 107-126.

Panikkar, P., Jagadeesh, T. D., Rao, D. S. K., Sarkar, U. K. and Naskar, M., 2015. First record of Non-native loricariid catfish, Pterygoplichthys disjunctivus (Webber, 1991) (Siluriformes, Loricariidae) in cauvery river of peninsular India. The Bioscan, 10, 16659-1663.

Paul, B. and Chanda, A., 2015. Small indigenous freshwater fish faunal diversity of Belda and its surroundings. IJBASR, 1, 06-09

Raghunathan, M. B., K. Devi, R and Indra, T. J., 2005. Studies on the ichthyofauna of sacred groves in Kanchipuram

\section{How to cite this article:}

Ramya V. L., S. Sibina Mol, D. S. Krishna Rao, Preetha Panikkar, M. Karthikeyan, P. K. Jesna, M. E. Vijaykumar and Sarkar U. K. 2019. New Record of Trichogaster lalius (Hamilton, 1822) from Thippagondanahalli Reservoir (Cauvery River Basin). Int.J.Curr.Microbiol.App.Sci. 8(10): 2521-2528. doi: https://doi.org/10.20546/ijcmas.2019.810.292
District, Tamilnadu. Rec. zoot. Surv., India, 104, 59-69.

Riehl, R. and Baensch, H. A., 1991. Aquarian Atlas.Band. 1. Melle: MergusVerlag fur atur-und. HeimtierKunde, Germany. Pp. 992. http://dx.doi.org/

Shim, K. F., Lam, T. J., and Landesman, L., 1987. Culture of the Dwarf Gourami Colisa lalia in Singapore. J. World Aquacult. Soc. 18, 203-206.

Talwar, P.K. and Jhingran, A. G., 1991. Inland fishes of India and adjacent countries (eds. Balkema A. A., Rotterdam, The Netherlands, Two volumes. 1991

USDA, 2016, Forest Service Invasive Species Program.

https://www.fs.fed.us/invasivespecies

Varunprasath, K. and Daniel, N. A., 2010. Comparison studies of three freshwater rivers (Cauvery, Bhavani and Noyal) in Tamilnadu, India. Iranica J. Energy and Environment. 1, 315-320.

Vishwanath, W. 2010. Trichogaster lalius. The IUCN Red List of Threatened Species: e.T166445A6210533. http://dx.doi.org/10.2305/IUCN.UK.20 104.RLTS.T166445A6210533.en.Dow nloaded on 07 October 2016.

Vishwanath, W. Trichogaster lalius. The IUCN Red List of Threatened Species 2010, e.T166445A6210533. http://dx.doi.org/10.2305/IUCN.UK.20 104.RLTS.T166445A6210533.en.Dow nloaded on 07 October 2016. 